\title{
Studi Kasus: Efektivitas Penggunaan Cairan Pembersih Luka Polyhexamethylene Biguanide Dengan Nano Silvosept Spray Dalam Mengurangi Biofilm Pada Ulkus Kaki Diabetik
}

\author{
Aisyah Nurlany ${ }^{1}$, Chrisyen Damanik ${ }^{2}$, Hamka ${ }^{3}$ \\ ${ }^{1}$ Mahasiswa Program Studi IImu Keperawatan ITKES Wiyata Husada Samarinda \\ e-mail: aisyahnurlany201@student.stikeswhs.ac.id \\ ${ }^{2}$ Dosen Program Studi IImu Keperawatan ITKES Wiyata Husada Samarinda \\ e-mail: chrisyendamanik@stikeswhs.ac.id \\ ${ }^{3}$ Praktisi Perawatan Luka, Fasilitas Pelayanan Kesehatan NCI Centre Kalimantan \\ e-mail: hamka.ncicentrekalimantan@gmail.com
}

\begin{abstract}
Abstrak
Latar belakang: Ulkus kaki diabetik merupakan salah satu komplikasi kronik dari diabetes yang sering ditemui. Kehadiran biofilm bakteri dianggap sebagai penghalang bagi perkembangan alami luka menuju penyembuhan dan memfasilitasi bioburden transisi dari kolonisasi sederhana ke kolonisasi kritis dan infeksi. Tujuan: Diketahuinya efektivitas penggunaan cairan pembersih luka polyhexamethylene biguanide dengan nano silvosept spray terhadap kemampuan mengurangi biofilm pada ulkus kaki diabetik. Metode: Kualitatif dengan pendekatan studi kasus, menggunakan teknik sampling, dengan jumlah partisipan 2. Pengukuran observasi dengan menggunakan Leg Ulcer Measurement Tool, dokumentasi dari rekaman arsip, dan triangulasi berupa wawancara dengan terapis yang mengetahui perkembangan luka dari awal hingga penelitian dilaksanakan. Hasil: Didapatkan keefektivan tindakan proses pencucian luka kaki diabetik dengan biofilm menggunakan pengkajian leg ulcers measurement tools pada setiap kasus terdapat penurunan skor baik dengan cairan pembersih luka polyhexamethylene biguanide maupun pembersih luka nano silvosept spray. Penurunan pada setiap skor terjadi baik secara keseluruhan maupun yang berfokus terhadap kondisi biofilm yang salah satunya ditandai dengan penurunan eksudat pada luka. Kedua cairan ini cukup baik untuk membersihkan luka dalam mengurangi biofilm yang mengganggu dalam proses penyembuhan luka. Kesimpulan: Keduanya efektif digunakan dalam perawatan luka kaki diabetik dengan biofilm baik polyhexamethylene biguanide maupun nano silvosept spray karena mempunyai cara tersendiri dalam menghilangkan bakteri selama proses pencucian luka.
\end{abstract}

Kata Kunci: Biofilm, Polyhexamethylene Biguanide, Nano Silvosept Spray

\section{PENDAHULUAN}

Diabetes mellitus merupakan suatu kelompok penyakit metabolik dengan karakteristik hiperglikemia, terjadi karena kelainan sekresi insulin, kerja insulin atau kedua-duanya (Decroli, 2019). Diabetes mellitus adalah epidemi di seluruh dunia dan merupakan tantangan besar bagi sistem perawatan kesehatan di dunia (Freitas et al.,
2017). Jumlah penderita DM di dunia dari tahun ke tahun terus mengalami peningkatan, sebanyak 366 juta jiwa di tahun 2011 meningkat menjadi 387 juta jiwa di tahun 2014 dan diperkirakan akan bertambah menjadi 592 juta jiwa pada tahun 2035. Penderita DM di dunia sebanyak $80 \%$ berasal dari negara berkembang salah satunya adalah Indonesia (Prastari et al., 
2017). Jumlah populasi penderita DM di Indonesia mencapai 12 juta jiwa pada tahun 2013, dan diprediksi akan terus meningkat setiap tahunnya. Di Kalimantan Timur, prevalensi DM diperkirakan sekitar 63.330 $(2,3 \%)$ jiwa dari total penduduk berumur $>14$ tahun (Infodatin, 2014).

Ulkus kaki diabetik (UKD) merupakan salah satu komplikasi kronik dari DM yang sering ditemui. Diperkirakan 2-10\% pasien DM mengalami ulkus diabetik setiap tahunnya dan sekitar $15-25 \%$ dari pasien tersebut akan mengalami ulkus diabetik selama hidupnya (Fortuna, 2016). Ulkus kaki diabetik adalah penyakit pada kaki penderita diabetes dengan karakteristik adanya neuropati sensorik, motorik, otonom dan atau gangguan pembuluh darah tungkai. Pada pasien DM dengan luka diabetik ini, perbaikan perfusi mutlak diperlukan karena hal tersebut akan sangat membantu dalam pengangkutan oksigen dan darah ke jaringan yang rusak. Bila perfusi perifer pada luka tersebut baik maka akan baik pula proses penyembuhan luka tersebut (Fleeson et al., 2017).

Pemulihan luka juga dipengaruhi oleh faktor, seperti: infeksi bakteri yang menghasilkan biofilm, kadar kalium, dan cairan luka. Adanya biofilm pada dasar luka dapat menghambat aktivitas fagositosis neutrofil polimorfonuklear. Kehadiran biofilm bakteri dianggap sebagai penghalang bagi perkembangan alami luka menuju penyembuhan (Ricci, E., \& Clinic, S. L.,
2016). Biofilm berlimpah di luka kronis seperti yang ditunjukkan oleh James et al didalam Bellingeri et al., (2016) yang melaporkan $60 \%$ dari luka kronis yang terkandung biofilm dibandingkan dengan $6 \%$ luka akut. Biofilm bertindak sebagai penghalang mekanis mengurangi kontak antimikroba dengan bakteri dan efektivitas mereka, dan memfasilitasi bioburden transisi dari kolonisasi sederhana ke kolonisasi kritis dan infeksi.

Tidak ada keraguan bahwa biofilm ada dalam beberapa luka, dan dalam dekade terakhir semakin banyak bukti pendukung yang muncul. Kemungkinan bahwa setidaknya setengah dari semua luka kronis mengandung biofilm, implikasinya cukup besar. Bukti terbaru dari model hewan telah menunjukkan bahwa biofilm menciptakan respon inflamasi tingkat rendah dan persisten, dan merusak baik epitelisasi dan pembentukan jaringan granulasi. Klaim bahwa biofilm kadang-kadang terlihat pada luka dengan mata telanjang telah dibahas di antara komunitas perawatan luka global. Lapisan mengkilap, tembus cahaya, dan berlendir di dasar luka telah digunakan sebagai tanda klinis biofilm, terutama jika ia kembali dengan cepat setelah debridemen telah dilakukan (Metcalf \& Bowler, 2013).

Pencucian luka dapat dilihat sebagai bagian integral dari persiapan luka dalam menciptakan lingkungan luka yang optimal dengan cara melepaskan benda asing, mengurangi jumlah bakteri dan mencegah 
aktivitas biofilm pada permukaan luka. Dengan demikian pencucian luka ini merupakan salah satu tindakan dari manajemen luka yang dilakukan untuk menghilangkan benda asing atau kuman patogen yang dapat menyebabkan infeksi pada luka guna mempercepat proses penyembuhan luka. (Wolcott \& Fletcher, 2014 didalam Nurbaya et al., 2018).

Pada dasarnya, pemilihan produk yang tepat harus berdasarkan pertimbangan biaya (cost), kenyamanan (comfort), dan keamanan (safety) (Kartika, 2015). Dalam hal ini untuk meningkatkan kenyamanan pasien pada penderita luka kaki diabetik dengan biofilm adalah dengan mengembangkan salah satu model teori kenyamanan Kolcaba. Model konseptual teori kenyamanan yang dikemukakan oleh Kolcaba dimana kenyamanan adalah status yang diungkapkan atau dirasakan oleh penerima terhadap suatu intervensi yang didapatkan. Hal ini merupakan pengalaman yang holistik dan memberikan kekuatan ketika seseorang membutuhkannya yang terdiri dari tiga bentuk kenyamanan, yaitu relief; ease dan transcendence, dalam empat konteks yaitu fisik, psikospiritual, sosiokultural dan lingkungan. Kenyamanan yang dirasakan pasien harus menjadi prioritas dan perhatian bagi perawat. (Hamid \& Ibrahim, 2017).

Penelitian ini bertujuan agar diketahuinya efektivitas penggunaan cairan pembersih luka polyhexamethylene biguanide dengan nano silvosept spray terhadap kemampuan mengurangi biofilm pada ulkus kaki diabetik.

\section{METODE PENELITIAN}

Penelitian ini menggunakan metode kualitatif dengan pendekatan studi kasus/case study. Adapun teknik pengambilan sampel dengan purposive sampling. Penelitian ini dilakukan dalam kurun waktu 2 minggu pada bulan Juni-Juli 2020 dengan sumber informan berasal dari pasien di Fasilitas Pelayanan Kesehatan $\mathrm{NCl}$ Centre Kalimantan site Samarinda. Partisipan dalam penelitian ini adalah pasien ulkus kaki diabetik dengan biofilm yang diberikan perawatan luka dengan cairan polyhexamethylene biguanide dan nano silvosept spray berjumlah 2 partisipan. Pemilihan partisipan ini menggunakan metode purposive sampling, yaitu: (1) Pasien luka kaki diabetik derajat 1-4 disertai biofilm yang menjalani perawatan luka di Fasilitas Pelayanan Kesehatan $\mathrm{NCl}$ Centre Kalimantan site Samarinda, (2) Seluruh partisipan yang telah menyetujui menjadi partisipan dibuktikan dengan pengisian informed concent, sehingga partisipan tidak merasa terpaksa selama mengikuti proses kegiatan penelitian.

\section{HASIL PENELITIAN}

a. Karakteristik Partisipan

Partisipan 1 berinisial Tn. $\mathrm{S}$, berusia 55 tahun, berjenis kelamin laki- 
laki, agama islam, bersuku jawa, pekerjaannya adalah sebagai pensiunan PNS, beralamat rumah di Jl. Loa Janan, $\mathrm{Km} \mathrm{1}$, dan memiliki riwayat penyakit diabetes melitus selama 5 tahun. Partisipan 2 berinisial Ny. U, berusia 60 tahun, jenis kelamin perempuan, agama islam, bersuku banjar, pekerjaannya adalah sebagai ibu rumah tangga, beralamat rumah di Jl. Loa Bakung, dan memiliki riwayat penyakit diabetes melitus selama 7 tahun.

b. Riwayat penyakit

Pada kasus pertama ini luka kaki diabetik dengan biofilm terletak pada kaki sebelah kanan dengan dua titik luka yaitu luka di bagian dalam kaki dan di pergelangan kaki bawah dengan bentuk kedua luka yaitu berbentuk lonjong. Pada partisipan pertama memiliki derajat luka 3 yaitu tampak tendon dan kapsul sendi. Sebelum melaksanakan perawatan luka di $\mathrm{NCl}$ Centre partisipan melakukan perawatan di rumah sakit dan dilakukan tindakan operasi pada kaki sebelah kanan dibuka untuk membantu mengeluarkan cairannya, kemudian dirawat dengan menggunakan betadin, tampak luka tidak kunjung membaik lalu dibawa ke pelayanan $\mathrm{NCl}$ Centre dan dilakukan perawatan luka sesuai dengan kondisi yang ada.

Pada kasus kedua ini luka kaki diabetik dengan biofilm terletak pada kaki sebelah kanan dengan dua titik luka yaitu luka di bagian mata kaki dan di jari telunjuk kaki dengan bentuk bulat dan tidak beraturan. Pada kasus ini partisipan memiliki derajat luka yaitu 2 atau ketebalan penuh. Sebelum mendapatkan perawatan luka di $\mathrm{NCl}$ Centre partisipan melakukan perawatan di rumah sakit dan dilakukan tindakan operasi pada jari telunjuk kaki, kemudian saat perawatan di rumah partisipan menggunakan betadin saat pembersihan luka, kemudian partisipan mendapatkan informasi mengenai pelayanan ini dan melaksanakan perawatan difasilitas pelayanan $\mathrm{NCl}$ ini, dan dilakukan perawatan luka sesuai dengan kondisi yang ada.

c. Laporan Kasus

1) Partisipan 1

Pada hari Kamis, 9 Juli 2020 telah dilakukan observasi pertama langsung kepada pasien. Observasi menggunakan instrumen pengkajian Leg Ulcer Measurement Tool (LUMT), setelah dilakukannya pencucian luka kaki diabetik dengan biofilm menggunakan cairan polyhexamethylene biguanide didapatkan skor total domain $A$ adalah 20 dan skor total domain $B$ adalah 5 , untuk total skor $A+B$ yaitu 25 , yang artinya masih terdapat luka pada kaki partisipan. 
Pada hari Senin, 13 Juli 2020 telah dilakukan observasi kedua langsung kepada pasien. Pada hasil observasi kedua dengan Leg Ulcer Measurement Tool (LUMT), setelah dilakukannya pencucian luka kaki diabetik dengan biofilm menggunakan cairan polyhexamethylene biguanide didapatkan skor total domain $A$ adalah 18 dan skor total domain $B$ adalah 4, untuk total skor $A+B$ yaitu 22, untuk skor yang mengalami penurunan adalah jumlah eksudat diberikan skor 2 yaitu sedikit, pengkajian bioburden diberikan skor 1 yaitu kolonisasi ringan dan skala nyeri diberikan skor 2 yaitu $>2-4$.

Pada hari Kamis, 16 Juli 2020 telah dilakukan observasi ketiga langsung kepada pasien. Pada hasil observasi ketiga dengan Leg Ulcer Measurement Tool (LUMT), setelah dilakukannya pencucian luka kaki diabetik dengan biofilm menggunakan cairan polyhexamethylene biguanide didapatkan skor total domain $A$ adalah 15 dan skor total domain $B$ adalah 4, untuk total skor $A+B$ menurun menjadi 19 yang artinya kondisi luka menjadi semakin membaik, untuk skor yang mengalami penurunan adalah tipe jaringan nekrotik diberikan skor 0 yaitu tidak ada, jumlah jaringan nekrotik diberikan skor 0 yaitu tidak tampak.

2) Partisipan 2

Pada hari Jumat, 10 Juli 2020 telah dilakukan observasi pertama langsung kepada pasien. Pada hasil observasi pertama dengan Leg Ulcer Measurement Tool (LUMT) setelah dilakukannya pencucian luka kaki diabetik dengan biofilm menggunakan cairan nano silvosept spray. Pada observasi pertama skor total domain $\mathrm{A}$ adalah 17 dan skor total domain $B$ adalah 3 , untuk total skor $A+B$ yaitu 20. Yang artinya masih terdapat luka pada kaki partisipan.

Pada hari Selasa, 14 Juli 2020 telah dilakukan observasi kedua langsung kepada pasien. Pada hasil observasi kedua dengan Leg Ulcer Measurement Tool (LUMT) setelah dilakukannya pencucian luka kaki diabetik dengan biofilm menggunakan cairan nano silvosept spray didapatkan skor total domain $A$ adalah 16 dan skor total domain $B$ adalah 3, untuk total skor A+B yaitu 19, untuk skor yang mengalami penurunan adalah tipe eksudat yang diberikan skor 1 yaitu serosanginosa, jumlah eksudat diberikan skor 2 yaitu sedikit, tipe jaringan nekrotik diberikan skor 0 yaitu tidak ada, jumlah jaringan nekrotik 
diberikan skor 0 yaitu tidak ada, dan pengkajian bioburden diberikan skor 1 yaitu kolonisasi ringan. Dan untuk kenaikan skor yaitu dari tipe edema kaki diberikan skor 2 yaitu pitting, lokasi edema kaki diberikan skor 2 yaitu bagian kaki meliputi ankle.

Pada hari Jumat, 17 Juli 2020 telah dilakukan observasi ketiga langsung kepada pasien, skor total domain $A$ adalah 14 dan skor total domain $B$ adalah 3 , untuk total skor $A+B$ yaitu 17, untuk skor yang mengalami penurunan adalah jumlah eksudat yang diberikan skor 1 yaitu sedikit sekali/hampir tidak ada, tipe jaringan edema kaki yang diberikan skor 1 yaitu non pitting atau kenyal.

\section{PEMBAHASAN}

Pada penelitian tampak bahwa pada saat terdapat biofilm pada luka tidak akan tampak jaringan granulasi luka oleh karena tertutup biofilm tersebut dan akan menghambat luka menuju penyembuhan. Hal ini seperti yang dikatakan didalam Ricci, E., \& Clinic, S. L., 2016, dimana pemulihan luka juga dipengaruhi oleh faktor, seperti: infeksi bakteri yang menghasilkan biofilm, kadar kalium, dan cairan luka. Adanya biofilm pada dasar luka dapat menghambat aktivitas fagositosis neutrofil polimorfonuklear. Kehadiran biofilm bakteri dianggap sebagai penghalang bagi perkembangan alami luka menuju penyembuhan.

Biofilm memainkan peran penting dalam ketidakmampuan luka kronis untuk sembuh. Diperkirakan lebih dari 90\% luka kronis mengandung bakteri dan jamur yang hidup dalam biofilm (Bowen G, 2016). Klaim bahwa biofilm terlihat pada luka dengan lapisan mengkilap, tembus cahaya, dan berlendir di dasar luka telah digunakan sebagai tanda klinis biofilm, terutama jika ia kembali dengan cepat setelah debridemen yang tajam (Metcalf \& Bowler, 2013). Secara teori, pembentukan jaringan mati dapat menghambat vaskularisasi pada granulasi, oleh karena itu perlu dilakukan pengangkatan jaringan mati atau yang disebut dengan debridement (Abidin, 2013).

Status kondisi luka juga dapat menggambarkan secara klinis adanya biofilm pada luka. Hal-hal yang dikaitkan dengan adanya biofilm pada luka diantaranya: adanya eksudat, gelatin pada permukaan luka, kontrol glikemik yang buruk, derajat luka, ukuran luka $(\leq 4 \mathrm{~cm})$, durasi luka (> 3 bulan), dan lama menderita DM (10-19 tahun). Observasi kehadiran biofilm juga dapat dilakukan secara visual melalui tanda klinis pada luka, salah satunya adalah adanya eksudat. Peningkatan jaringan nekrotik dan eksudat meningkatkan kecurigaan akan keberadaan biofilm (Majid S, 2019).

Berdasarkan hasil penelitian, dari segi observasi dengan menggunakan Leg Ulcer 
Measurement Tools disemua kasus baik kasus pertama hingga kasus kedua mengalami penurunan pada tiap skornya. Hal ini dikarenakan para perawat menggunakan teknik modern dressing dan juga berbagai upaya yang maksimal selama proses perawatan untuk mencapai kesembuhan yang baik. Dalam Nair (2019) penelitiannya diperoleh hasil bahwa total 17 pasien menunjukkan peningkatan yang baik dalam hal ukuran luka dan pengurangan tanda-tanda infeksi (seperti peradangan, kemerahan, eksudat, bau, dan biofilm) tanpa reaksi alergi. Aplikasi nano koloidal silver dihentikan setelah gejala infeksi telah hilang sementara balutan terus diterapkan sampai penutupan penuh luka. Maksudnya adalah dari hal tersebut terdapat perbedaan antara kondisi luka sebelum perawatan luka dengan sesudah perawatan luka.

Pada luka diabetik kasus pertama ini penanganan luka kaki diabetik dengan biofilm dilakukan dengan prosedur 3M yaitu mencuci, mengangkat jaringan mati, dan mengganti balutan. Untuk menghilangkan biofilm yang ada pada luka, setelah dicuci luka dikompres menggunakan cairan pencuci luka polyhexamethylene biguanide, kemudian di diamkan selama 10 menit dan ditutup kassa, setelah itu kassa dibuka dan beberapa biofilm mulai terangkat dan yang terdapat diluka dibersihkan menggunakan teknik mekanikal debridemen yaitu dengan menggunakan pinset, gunting dan kassa. Biofilm sangat menganggu dalam proses luka menuju penyembuhan salah satunya menghambat proses epitel luka, karena konsep moist yang ada pada polyhexamethylene biguanide dan dibantu dengan teknik mekanikal debridement untuk pengangkatan jaringan mati, maka jaringan luka yang bagus akan terlihat sehinggan balutan yang digunakan dapat bekerja lebih efektif terhadap proses penyembuhan luka.

Pada penelitian yang dilakukan pada cairan pencuci luka polyhexamethylene biguanide walaupun waktu yang digunakan 10 menit namun mampu mengurangi biofilm pada luka dengan menempel pada kassa yang diberikan pada luka. Pada cairan pencuci nano silvosept spray waktu yang digunakan 3 menit mampu mengurangi biofilm luka dengan cepat menggunakan kassa, pinset dan gunting. Pencucian luka yang dilakukan pada partisipan 1 adalah polyhexamethylene biguanide dan pada partisipan 2 menggunakan cairan pencuci luka nano silvosept spray. Kedua cairan ini cukup baik untuk membersihkan luka dalam mengurangi biofilm yang mengganggu dalam proses penyembuhan luka, sesuai dengan teori dari Butcher (2012) bahwa polyhexamethylene biguanide memiliki spektrum aktivitas yang luas dalam melawan bakteri, virus dan jamur yang dapat menginduksi kematian sel. Polyhexamethylene biguanide bekerja dengan menyusup ke selaput sel bakteri dan membunuh bakteri tersebut. Menurut Nair (2019) bahwa nano silver efektif dalam 
mengurangi bioburden dan peradangan, karena bentuk dan ukuran nano partikelnya yang mampu menyerap ke dalam lingkungan luka dan dinding bakteri karena bentuk dan ukurannya tersebut.

Pada hasil penelitian terlihat bahwa pada kedua partisipan dengan pemakaian baik cairan pencuci luka polyhexamethylene biguanide maupun cairan pencuci luka nano silvosept spray tidak menunjukan adanya efek samping dalam penggunaannya, yang artinya cairan ini aman bagi tubuh. Seperti yang dijelaskan didalam Butcher, 2012 bahwa sensitisasi kulit terhadap polyhexamethylene biguanide rendah. $\mathrm{Di}$ dalam Kordestani S., et al, 2014 juga menjelaskan bahwa nano silvosept tidak berbau dan tidak berwarna, tidak ada iritasi, tidak ada sensitivitas, tidak ada toksisitas, dan tidak ada genotoksisitas.

Selain itu, teknik lembab dalam perawatan luka juga harus diperhatikan dimana bahwa untuk balutan basah kering apabila luka memiliki eksudat dalam jumlah banyak maka harus segera diganti balutannya. Terutama apabila eksudat tersebut sampai merembes keluar dari balutan yang menyebabkan balutan tampak kotor. Perawatan luka dengan balutan basah kering akan sangat sulit saat ingin membuka balutan tersebut dikarenakan balutan tersebut menjadi kering dan akan menimbulkan nyeri dan juga perdarahan apabila balutan tersebut diangkat serta dapat merusak sel-sel. Sedangkan teknik moist wound healing merupakan teknik penangganan luka dengan cara menjaga keadaan luka agar tetap lembab sehingga dapat menfasilitasi pergerakan sel pada luka, serta dapat mempercepat proses granulasi. Teknik moist wound healing ini menunjukkan bahwa eksudat luka dapat memberikan bahan-bahan yang dibutuhkan dalam proses penyembuhan, seperti enzim, growth factors, dan faktor kemotaktik dimana dapat mengendalikan infeksi, serta dapat menyediakan lingkungan yang terbaik dalam proses penyembuhan (Ose, 2018; Yunita, 2019).

Selain itu pada pelaksanaan perawatan luka kaki diabetik dengan biofilm juga perlu memperhatikan aspek kenyamanan bagi pasien untuk meningkatkan kepuasan pelayanan dan feedback yang baik untuk instansi itu sendiri, seperti yang dijelaskan didalam Hamid \& Ibrahim, 2017 yang menyatakan bahwa kenyamanan adalah status yang diungkapkan atau dirasakan oleh penerima terhadap suatu intervensi yang didapatkan. Hal ini merupakan pengalaman yang holistik dan memberikan kekuatan ketika seseorang membutuhkannya yang terdiri dari tiga bentuk kenyamanan, yaitu Relief adalah keadaan dimana perawat meringankan kebutuhan yang diperlukan oleh pasien. Ease adalah keadaan dimana seseorang tenang atau mencapai kepuasan. Transcendence adalah keadaan dimana 
Jurnal Keperawatan Wiyata

Volume 2, Nomor 1, Tahun 2021

ISSN 2774-4558 (Cetak)

ISSN 2774-9789 (Online)

Halaman 51-60

perawat membantu pasien dalam mengatasi

kesulitannya.

\section{KESIMPULAN}

Berdasarkan hasil observasi yang dilakukan terhadap proses pembersihan luka kaki diabetik berbiofilm dengan menggunakan cairan pembersih luka polyhexamethylene biguanide dengan cairan pencuci luka nano silvosept spray menggunakan pengkajian leg ulcers measurement tools didapatkan keefektivan tindakan proses pencucian luka pada pasien 1 dari skor 25 menjadi 19, pada pasien 2 dari skor 20 menjadi 17 . Penurunan pada setiap skor terjadi baik secara keseluruhan maupun yang berfokus terhadap kondisi biofilmnya. Kemudian dalam studi kasus ini, baik polyhexamethylene biguanide maupun nano silvosept spray mempunyai cara tersendiri dalam menghilangkan bakteri selama proses pencucian luka.

\section{DAFTAR PUSTAKA}

Abidin K. R., dkk. (2013). Faktor Penghambat Proses Proliferasi Luka Diabetic Foot Ulcer Pada Pasien Diabetes Mellitus Tipe II Di Klinik Kitamura Pontianak. Universitas Tanjungpura

Bellingeri, A., Falciani, F., Traspedini, P., Moscatelli, A., Russo, A., Tino, G., ... Peghetti, A. (2016). Effect Of A Wound Cleansing Solution On Wound Bed Preparation And Inflammation In Chronic Wounds: A Single-Blind RCT. Journal of Wound Care, 25(3), 160-168. http://doi.org/10.12968/jowc.2016.25.

\subsection{0}

Bowen G \& Richardon N (2016). Biofilm Management in Chronic Wounds and Diabetic Foot Ulcers. The Diabetic Foot Journal 19: 198-204

Butcher M. (2012). PHMB: An Effective Antimicrobial in Wound Bioburden Management. British Journal of Nursing, 2012 (Tissue Viability Supplement), Vol 21, No 12

Decroli E. (2019). Diabetes Melitus Tipe 2. Padang: Pusat Penerbitan Bagian IImu Penyakit Dalam Fakultas Kedokteran Universitas Andalas. ISBN No. 978-602-1332-25-2

Fleeson, W., Jayawickreme, E., Jones, A. B. A. P., Brown, N. A., Serfass, D. G., Sherman, R. A., ... Matyjek-, M. (2017). PENGARUH PERAWATAN LUKA DENGAN MODERN DRESSING TERHADAP KUALITAS HIDUP PASIEN ULKUS DIABETIKUM. Journal of Personality and Social Psychology. https://doi.org/10.1111/j.1469-

7610.2010.02280.x

Freitas, P. A. C., Ehlert, L. R., \& Camargo, J. L. (2017). Glycated albumin: a potential biomarker in diabetes. Archives of Endocrinology and Metabolism.

https://doi.org/10.1590/23593997000000272

Hamid A.Y.S \& Ibrahim K. (2017). Pakar Teori Keperawatan dan Karya Mereka. Edisi Indonesia Ke-8. Volume 2. Elsevier Singapore Pte Ltd. ISBN Volume 2: 978-981-457077-0

Infodatin Pusat Data dan Informasi Kementrian Kesehatan RI. (2014). Situasi dan Analisis Diabetes.

Kartika, R.W. (2015). Perawatan Luka Kronis dengan Modern Dressing. TEKNIK. 
https://doi.org/10.1111/j.1469-

0691.2008.02685.x

Majid S., dkk. (2019). Identifikasi dan Peran Biofilm dalam Proses Penyembuhan Luka Kaki Diabetes: Tinjauan Literatur. Makassar: Universitas Hassanudin. Jurnal IImu Kesehatan Vol. 8. No. 1, Nopember 2019. ISSN: 2303-1433

Metcalf D.G \& Bowler P.G. (2013). Biofilm Delays Wound Healing: A Review og The Evidence. Burns \& Trauma, June 2013, Vol 1, Issue 1. DOI: 10.4103/2321-3868.113329

Nair H. K. (2019). Managing Inftion in Chronic Wounds with Nano Colloidal Silver. Wounds Asia 2019. Vol 2 Issue 2

Ose, M. I., Utami, P. A., \& Damayanti A. (2018), Efektivitas Perawatan Luka Teknik Balutan Wetdry Dan Moist Wound Healing Pada Penyembuhan Ulkus Diabetik. Journal of Borneo Holistic Health, Volume 1 No. 1 Juni 2018 hal 101-112.

Prastari, C., Yasni, S., Nurilmana, M., \& Nurilmala, M. (2017). KARAKTERISTIK PROTEIN IKAN GABUS YANG BERPOTENSI SEBAGAI ANTIHIPERGLIKEMIK. JPHPI.

https://doi.org/10.17844/jphpi.v20i2.1 8109

Ricci, E., \& Clinic, S. L. (2016). The Management of Chronic Ulcers With an Acidoxidising Solution. Journal of Wound Care. Vol 25, No 8, August 2016 